\title{
PEMBINAAN KOMPETENSI USTADZ MADRASAH DINIYAH MELALUI PROGRAM TARBIYATUL MU'ALLIMIN DI MADRASAH DINIYAH TAKMILIYAH AWWALIYAH AR- ROSYIDIYAH MAMBAUL ULUM PANGARENGAN SAMPANG
}

\author{
Miftahul Ulum
}

Email: Miftahul_ulum2001@yahoo.com

STAI Syaichona Moh. Cholil Bangkalan

\section{Faizatul Muazzaroh}

Email: faizatul_muazzaroh@ymailcom

STAI Syaichona Moh. Cholil Bangkalan

\begin{abstract}
Abstrak:
Program Tarbiyatul Mu'allimin merupakan sebuah wadah pembinaan yang diadakan untuk memberikan pembekalan sekaligus meningkatkan penguasaan materi seorang ustadz khususnya dalam bidang ilmu agama. Tehnik pengumpulan data dilakukan dengan metode observasi partisipan, wawancara tidak terstruktur, dan metode dokumentasi. Analisis data yang dilakukan yaitu selama penelitian dan setelah penelitian dilakukan. Hasil penelitian menunjukkan bahwa program tarbiyatul mu'allimin dilaksanakan setiap hari pada jam 16.00-17.00 (istiwa'). Bentuk pelaksanaannya sama dengan pelaksanaan KBM yang dilaksanakan di kelas biasanya. Metode yang biasa digunakan adalah metode ceramah dan tanya jawab. Dan materi kajiannya meliputi 8 bidang ilmu yaitu: 'ilmu ushūl (kitab Jawharoh atTauhīid), 'ilmu furu' (kitab Fathul al-Qarīb), tafsīr (kitab Tafsīr Jalalain), 'ilmu hadits (kitab Riyad as-Sholihinin), 'ilmu alat (kitab Ibnu Aqīl), ilmu qushos (kitab Daqoiqul Akhbar), 'ilmu sufi (kitab Bidāyatul Hidāyah), 'ilmu akhlak (kitab Ta'limul Muta'allim dan 'Uqudul Lijain). Kendala yang dihadapi dalam penerapan program Tarbiyatul Mu'allimin pada pembinaan kompetensi ustadz diantaranya: minimnya minat atau kemauan para asatidz untuk konsisten mengikuti program dengan alasan malas atau sibuk bekerja, waktu yang kurang memadai, kegiatan sosial masyarakat seperti tahlilan. Upaya yang dilakukan dalam mengatasi kendala yaitu dengan memberikan pemantapan dan meyakinkan para asatidz akan pentingnya mengikuti program Tarbiyatul Mu'allimin untuk menambah dan memperluas penguasaan materi yang akan disampaikan pada murid-muridnya. Selain itu, kepala madrasah juga memberikan tunjangan.
\end{abstract}

Kata kunci: kompetensi, ustadz, tarbiyatul mu'allimin 


\section{Pendahuluan}

Berhasil tidaknya suatu pendidikan ditentukan oleh peran serta seorang guru karena guru merupakan pemegang peran kunci untuk mengatur dan menjalankan kegiatan pembelajaran. Oleh sebab itu, simbol guru selalu muncul kepermukaan menjadi topik diskusi, seminar, dan pertemuan lainnya yang selalu aktual dibahas lantaran permasalahan yang dihadapi tenaga edukatif itu tidak pernah usai. ${ }^{1}$

Seiring perkembangan zaman, saat ini dedikasi seorang guru pun juga mulai mengalami kemerosotan bahkan tak jarang yang dalam mengajarnya hanya sebatas menyampaikan materi dan menggugurkan kewajiban saja tanpa memberi contoh dalam kehidupan sehari-hari. Sementara ia merupakan figur utama bagi anak didik untuk dijadikan teladan. Maka, penting untuk terus menanamkan dan memupuk nilainilai keislaman dalam diri seorang guru. Selain itu, moral anak didik pada saat ini sungguh menyedihkan, hal ini menandakan adanya ketidak berhasilan dalam mendidik aset bangsa tersebut.

Mengingat potret pendidikan yang seperti itu, ada suatu lembaga yang menarik perhatian dan membangkitkan semangat peneliti untuk mencari tahu lebih dalam tentang seluk beluk lembaga tersebut. Karena lembaga tersebut telah memberikan perhatian khusus bagi tenaga pendidiknya dengan memberikan sebuah pelayanan dan pembekalan terkait dengan penguasaan pendidikan agama mereka. Sehingga nantinya para pendidik yang akrab dengan sebutan ustadz tersebut bisa memiliki penguasaan agama yang baik dan bekal yang cukup untuk menjalankan tugas dan tanggung jawabnya.

Pembinaan kompetensi guru yang dalam hal ini adalah ustadz tidak hanya penting bagi sekolah, tetapi juga bagi ustadz yang bersangkutan guna membantu mereka memahami kemampuan, kelebihan, kekurangan, dan potensi yang dimilikinya, sehingga nantinya bisa dijadikan bahan pertimbangan dalam menentukan rencana dan pengembangan karier. Sedangkan bagi pihak sekolah, peningkatan kompetensi sangat penting sebagai bahan pertimbangan dalam pengambilan keputusan berbagai hal, seperti penempatan, pembagian tugas, dan berbagai hal lain dalam kaitannya dengan pengembangan sumber daya tenaga kependidikan disekolah tersebut. ${ }^{2}$

Terkait dengan hal tersebut, maka penulis merasa tertarik untuk meneliti tentang Pembinaan Kompetensi Ustadz di Madrasah Diniyah melalui Program Tarbiyatul Mu'allimin di Madrasah Diniyah Takmiliyah Awwaliyah Ar-rosyidiyah Mambaul Ulum Pangarengan Sampang.

\footnotetext{
${ }^{1}$ Ahmad Barizi, Pendidikan Integratif; Akar Tradisi \& Integrasi Keilmuan Pendidikan Islam (Malang: UIN Maliki Press, 2011), 25.

${ }^{2}$ Kompri, Manajemen Pendidikan: Komponen-Komponen Elementer Kemajuan Sekolah (Yogyakarta: ArRuzz Media, 2015), 140.
} 
Fokus dalam penelitian ini adalah: Bagaimana penerapan program Tarbiyatul Mu'allimin pada pembinaan kompetensi ustadz madrasah diniyah di Madrasah Diniyah Takmiliyah Ar-Rosyidiyah Mambaul Ulum?, apa saja kendala yang dihadapi dalam penerapan program Tarbiyatul Mu'allimin pada pembinaan kompetensi ustadz madrasah diniyah di Madrasah Diniyah Takmiliyah Ar-Rosyidiyah Mambaul Ulum?, dan bagaimana mengatasi kendala yang dihadapi dalam penerapan program Tarbiyatul Mu'allimin pada pembinaan kompetensi ustadz madrasah diniyah di Madrasah Diniyah Takmiliyah Ar-Rosyidiyah Mambaul Ulum?

\section{Pengertian Pembinaan}

Pembinaan berasal kata bina yang dalam Kamus Besar Bahasa Indonesia memiliki arti mengusahakan supaya lebih baik (maju, sempurna, dsb). Sedangkan kata Pembinaan sendiri berarti perihal membina, pembaruan; penyempurnaan. ${ }^{3}$ Dengan demikian, dapat dikatakan bahwa pembinaan adalah sebuah upaya pembenahan atau pembaharuan yang dilakukan oleh seorang atasan pada bawahannya baik secara langsung atau melalui perantara tenaga ahli lain yang berupa pemberian bimbingan atau layanan lainnya guna mencapai sebuah penyempurnaan.

Menurut Widjaja sebagaimana dikutip oleh Hendrikus Lyzardi Kurniawan, et. al., pembinaan adalah suatu proses atau pengembangan yang mencakup urutanurutan pengertian yang diawali mendirikan, menumbuhkan dan memelihara pertumbuhan tersebut disertai usaha-usaha perbaikan, penyempurnaan dan akhirnya mengembangkannya. ${ }^{4}$

Lebih lanjut Zakiyah Dradjat sebagaimana diposting oleh Rani, ia mengemukakan bahwa pembinaan adalah upaya pendidikan baik formal atau non formal yang dilaksanakan secara sadar, terencana, terarah, dan bertanggung jawab dalam rangka memperkenalkan, menumbuhkan dan mengembangkan suatu dasar kepribadian yang seimbang dan selaras. ${ }^{5}$

Dari beberapa pendapat para ahli dapat disimpulkan bahwa pembinaan adalah sebuah upaya yang dilakukan oleh instansi/lembaga maupun organisasi sebagai bentuk tindak lanjut dalam memperbaiki atau meningkatkan kinerja anggotanya guna mencapai suatu kemajuan.

\footnotetext{
3 Tim Penyusun Kamus Pusat Bahasa, Kamus Besar Bahasa Indonesia, offline (Jakarta: Pusat Bahasa, 2008), 202.

4 Hendrikus Lyzardi Kurniawan, et al., 2014. Pembinaan Sumber Daya Aparatur dalam Upaya Meningkatkan Kinerja Pegawai pada Bagian Ekonomi Sekretariat Daerah Kabupaten Kutai Barat. eJournal Administrative Reform, 2 (3): 2118.

5Rani, Upaya Pembinaan Profesinal Guru: http://raniaja606/.blogspot.co.id/2014/05/upaya-pembinaan-kompetensi-profesional.html. Diakses 26 April 2017.
} 
Adapun pembinaan guru, secara terminologis sering diartikan sebagai serangkaian usaha bantuan kepada guru, terutama bantuan yang berwujud layanan profesional untuk meningkatkan proses dan hasil belajar. ${ }^{6}$

Berdasar pada pernyataan tersebut, maka penulis menyimpulkan bahwasanya yang dimaksud dengan pembinaan guru adalah sebuah upaya pemberian layanan sebagai wujud bantuan peningkatan kapasitas dan kapabilitas yang diberikan pada seorang guru guna terciptanya tenaga profesional yang mampu menciptakan suasana menyenangkan dalam proses belajar mengajar yang nantinya akan berdampak pada peningkatan hasil belajar.

\section{Tujuan Pembinaan}

Adapun tujuan umum pembinaan sebagai berikut :

a. Untuk mengembangkan keahlian, sehingga pekerja dapat menyelesaikan pekerjaannya lebih cepat.

b. Untuk mengembangkan pengetahuan, sehingga pekerja dapat menyelesaikan pekerjaannya secara rasional, dan

c. Untuk mengembangkan sikap, sehingga menimbulkan kemauan kerjasama dengan teman-teman pegawai dan dengan manajemen yang baik (pemimpin). ${ }^{7}$

Berdasarkan tujuan umum pembinaan tersebut dapat dipahami bahwa tujuan pembinaan kompetensi guru adalah untuk memberikan bantuan atau bimbingan pada guru dalam mengembangkan situasi belajar mengajar yang lebih baik.

\section{Fungsi Pembinaan}

Pembinaan memiliki beberapa fungsi, diantaranya:

a. Memupuk kesetiaan dan ketaatan.

b. Meningkatkan adanya rasa pengabdian, rasa tanggung jawab, kesungguhan dan kegairahan bekerja dalam melaksanakan tugasnya.

c. Meningkatkan gairah dan produktivitas kerja secara optimal.

d. Mewujudkan suatu layanan organisasi dan pegawai yang bersih dan berwibawa.

e. Memperbesar kemampuan dan kehidupan pegawai melalui proses pendidikan dan latihan yang sesuai dengan kebutuhan dan perkembangan organisasi (wadah yang ditentukan). ${ }^{8}$

Berdasarkan fungsi tersebut dapat dipahami bahwa fungsi pembinaan guru adalah untuk meningkatkan profesionalitas seorang guru dalam mengemban dan

\footnotetext{
${ }^{6}$ Hamzah B. Uno, Model Pembelajaran: Menciptakan Proses Belajar Mengajar yang Kreatif dan Efektif (Jakarta: Bumi Aksara, 2012), 169.

${ }^{7}$ Digilib.unila.ac.id/930/9/BAB II.pdf. Diakses 26 April 2017.

${ }^{8}$ Pengertian, Fungsi Pembinaan Menurut Para Ahli, Kumpulan Artikel tentang Komputer, Internet, dan juga Pelajaran Sekolah dan Artikel Lainnya:http://xerma.blogspot.co.id/2014/05/pengertian-fungsipembinaan-menurut.html. Diakses 25 April 2017.
} 
menjalankan tugasnya sebagai pendidik yang berkualitas yang bisa mengantarkan anak didiknya pada pintu keberhasilan dalam mengenyam pendidikan.

\section{Faktor Pendukung atau Penghambat Pembinaan}

Menurut H.AR Tilaar sebagaimana dikutip oleh Saiful Arif, permasalahan yang seringkali dijumpai dalam pembinaan dan pengembangan profesional ustadz diantaranya para guru cenderung ingin melihat hasilnya yang cepat, sedangkan pembinaan tersebut harus melalui pelaksanaan dilapangan sehingga meminta waktu yang cukup. Dan disisi lain di dalam program pembinaan tersebut ingin mengumpulkan guru sebanyak mungkin dan oleh sebab itu program-program tersebut bersifat sangat dangkal. ${ }^{9}$

Selaras dengan perihal di atas, dalam pengimplementasiaan wadah pembinaan profesional pun masih ditemukan ada yang belum berjalan sebagaimana fungsinya, seperti halnya dalam MGMP. Kegiatan yang diselenggarakan sebagian besar masih cenderung bersifat administratif, seperti membuat Satuan Pelajaran (SATPEL), mengisi angka kredit, dan kegiatan-kegiatan lainnya. Sementara itu, hal-hal yang berkaitan dengan teknik edukatif seperti membahas permasalahan mengajar di kelas, bagaimana mengahadapi kasus-kasus murid tertentu, dan bagaimana memberikan evaluasi yang tepat kepada siswa masih mendapat porsi yang sedikit. ${ }^{10}$

Kegiatan yang bersifat pelatihan pun juga masih cenderung mengulang materi yang sudah disampaikan di Lembaga Pendidikan Tenaga Keguruan, dan cenderung tidak memenuhi standar efisiensi maupun efektiviitas. Indikasi demikian terjadi karena baik klien (Departemen Pendidikan Nasional) maupun pemangku kepentingan (kepala dinas, pegawai pendidikan, dan kepala sekolah) masih belum berkonsentrasi secara optimal terhadap faktor-faktor yang memengaruhi tingkat tingkat efisiensi dan efektifitas. Faktor-faktor ini meliputi alokasi biaya pelatihan, isi program pelatihan, kelayakan fasilitas yang digunakan, kesesuaian peserta dengan program pelatihan, kemampuan instruktur/peslatih dalam menyampaikan materi pelatihan, serta pengetahuan tentang prinsip-prinsip belajar. Sementara itu, faktorfaktor yang terkait langsung dengan materi atau substansi pelatihan masih bersifat parsial, yaitu belum memuat seluruh aspek yang mengetahui tingkat mutu pendidikan. ${ }^{11}$

Berdasarkan uraian tersebut dapat dipahami bahwa faktor pendukung dan penghambat pembinaan guru terletak pada pastisipasi dan perhatian penuh baik dari

\footnotetext{
${ }^{9}$ Saiful Arif, "Orientasi Pembinaan dan Pengembangan Profesi Guru di Madrasah." Tadris,8 (juni, 2013), 143.

${ }^{10}$ Hamzah B. Uno \& Nina Lamatenggo, Tugas Guru dalam Pembelajaran: Aspek yang Memengaruhi (Jakarta: Bumi Aksara, 2016), 9.

${ }^{11}$ Ibid.,
} 
pihak lembaga yang mengadakan pembinaan maupun orang-orang yang terkait, dan khususnya kesadaran guru akan hak dan kewajibannya sebagai pendidik. 


\section{Pengertian Ustadz}

Dalam Kamus Besar Bahasa Indonesia disebutkan bahwa Ustadz adalah ahli agama (laki-laki), guru atau guru besar (pada madrasah dsb). ${ }^{12}$ Hal yang sama juga disebutkan dalam Kamus Al-Munawwir bahwa Ustadz yang jamaknya adalah asatidzah (أساتذةٌ) dan asatidz (أساتيذ) memiliki makna Guru. ${ }^{13}$ Dengan demikian, dapat dikatakan bahwa Guru dan Ustadz merupakan satu kesatuan dan sama-sama ditujukan pada seorang pendidik, hanya saja penyebutannya yang berbeda. Guru biasanya digunakan untuk menyebut tenaga pendidik yang mengajar disekolah umum/formal, sedangkan ustadz atau ustadzah digunakan untuk sebutan pendidik yang mengajar dilingkungan Madrasah, pondok pesantren atau mengajar pendidikan agama. Oleh karena itu, meski disini banyak mengulas tentang guru tapi pada dasarnya itu juga ditujukan pada ustadz.

Guru yang dalam hal ini ustadz adalah salah satu komponen manusiawi dalam proses belajar mengajar yang ikut berperan dalam usaha pembentukan sumber daya manusia yang potensial dibidang pembangunan. Oleh karena itu, ustadz yang merupakan salah satu unsur dibidang kependidikan harus berperan serta secara aktif dan menempatkan kedudukannya sebagai tenaga profesional sesuai dengan tuntutan masyarakat yang semakin berkembang. ${ }^{14}$

Dalam literatur kependidikan Islam, seorang guru/pendidik biasa disebut sebagai ustadz, mu'allim, murabbiy, mursyid, mudarris, dan mu'addib. ${ }^{15}$ Meskipun semua sebutan-sebutan tersebut ditujukan pada seorang pendidik, tapi dalam prakteknya memiliki karakteristik dan tugas yang berbeda. Sejalan dengan hal itu, Mehdi Nakosteen juga menjelaskan bahwa ada enam tipe guru dalam pendidikan Islam diantaranya: Mu'allim, Mu'addib, Mudarris, Syaikh, Ustadz, dan Imam. ${ }^{16}$

Dari hasil telaah terhadap istilah-istilah guru tersebut, penulis memahami bahwa meskipun semua istilah tersebut ditujukan pada orang yang mengajar dan

\footnotetext{
12 Tim Penyusun Kamus Pusat Bahasa, Kamus Besar Bahasa Indonesia,1601.

13 Ahmad Warson Munawwir, Al-Munawwir: Kamus Arab-Indonesia (Surabaya: Pustaka Progressif, 1997), 23.

${ }^{14}$ Sardiman, Interaksi \& Motivasi Belajar Mengajar (Jakarta: PT Raja Grafindo Persada, 2010), 125.

15 Muhaimin, Pengembangan Kurikulum Pendidikan Agama Islam di Sekolah, Madrasah, dan Perguruan Tinggi (Jakarta: PT Raja Grafindo Persada, 2010), 44.

16 Mu'allim biasanya untuk julukan guru-guru sekolah dasar. Mu'addib arti harfiahnya orang yang beradab atau guru adab yakni guru-guru sekolah dasar dan menengah. Mudarris adalah julukan profesional untuk seorang mu'id atau asisten dan sama dengan asisten professor yang bertugas membantu mahasiswa menjelaskan hal-hal yang sulit mengenai kuliah yang diberikan profesornya. Syaikh adalah julukan khusus yang menggambarkan keunggulan akademis dalam bidang teologis. Imam adalah guru agama tertinggi. Lihat Mehdi Nokesteen, History of Islamic Origins of Western Education (Colorado: University of Colorado Press), 56.
} 
mendidik. Akan tetapi, penyebutan istilah guru yang dikemukakan oleh Muhaimin dan Nakosteen memiliki titik perbedaan. Muhaimin lebih menitik beratkan kepada peran dan fungsi guru sebagai pendidik, sedangkan Nakosteen lebih menitik beratkan kepada julukan atau gelar saja. Selanjutnya, di dunia madrasah khususnya madrasah diniyah dari istilah-istilah tersebut julukan yang kerap terdengar dan akrab ditelinga kita adalah ustadz. ${ }^{17}$

Disamping istilah-istilah atau predikat di atas, dalam tradisi Islam Indonesia ditemukan pula beberapa predikat bagi guru yang biasanya berbeda dalam setiap daerah. Misalnya, Kyai dipulau jawa dan madura, Ajengan di Jawa Barat, Tuan Guru di Lombok, dan Teuku di Aceh. 18

Dengan demikian, dapat dipahami bahwa pada hakekatnya sebutan guru dan ustadz sama-sama tertuju pada seorang pendidik yakni sosok yang tidak hanya menjalankan tugasnya dengan transfer of knowledge saja tapi juga transfer of value sehingga ia bukan hanya membentuk anak didiknya untuk menjadi pribadi yang pandai dalam bidang keilmuan saja tapi juga memiliki akhlakul karimah. Jadi, meski kerap terjadi perbedaan penyebutan yakni guru digunakan sebagai sebutan bagi tenaga pendidik yang mengajar pendidikan umum, dan ustadz digunakan untuk menyebut tenaga pendidik yang mengajar pendidikan agama tapi sebenarnya mau menggunakan istilah guru atau ustadz sama saja.

\section{Kompetensi Ustadz}

Dalam Peraturan Pemerintah Nomor 74 Tahun 2008 tentang Guru, khususnya yang terdapat dalam Bab II Pasal 3 ayat (1) disebutkan bahwa Kompetensi merupakan seperangkat pengetahuan, keterampilan, dan perilaku yang harus dimiliki, dihayati, dikuasai, dan diaktualisasikan oleh Guru dalam melaksanakan tugas keprofesionalan. ${ }^{19}$ Sedangkan Menurut Fessler dan Guest sebagaimana dikutip oleh Pupuh Fathurrohman dan Aa Suryana, kompetensi didefinisikan sebagai karakteristik

\footnotetext{
17 Ustadz adalah sebuah sebutan untuk guru agama Islam laki-laki. Sedangkan sebutan untuk guru agama Islam perempuan adalah ustadzah. Lihat Abu Muhammad FH \& Zainuri Ziroj, Kamus Istilah Agama Islam (KIAI) (Tangerang: PT Albama, 2009), 330. Lebih lanjut Herabuddin menyatakan bahwa Sebutan guru agama lebih populer digunakan di sekolah selain madrasah seperti sekolah umum atau kejuruan sebagai sebutan untuk guru yang mengajar mata pelajaran agama Islam. Sedangkan untuk sekolah madrasah tidak memopulerkan sebutan gurunya dengan guru agama, karena pendidikan madrasah telah disebut pendidikan agama. Sehingga hampir semua guru di madrasah dipanggil dengan sebutan ustadz. Lihat Herabudin, Administrasi \& Supervisi Pendidikan (Bandung: Pustaka Setia, 2009), 269.

18 Mohammad Kosim, "Guru dalam Perspektif Islam", dalam Memotret Guru Ideal-Profesional: Harapan, Peluang, dan Tantangan di Tengah Arus Perubahan Sosial, ed. Mohammad Muchlis Solichin (Surabaya: Pena Salsabila, 2013), 4.

${ }_{19}$ Peraturan Pemerintah RI Nomor 74 Tahun 2008 tentang Guru (Jakarta: Presiden RI, 2008), 5.
} 
yang mendasari seseorang dan berkaitan dengan efektivitas kinerja individu dalam pekerjaannya. $^{20}$

Dari uraian pendapat tersebut penulis memahami dan mencoba menyimpulkan bahwa kompetensi guru adalah sebuah pengetahuan yang harus dimiliki oleh seorang guru sesuai bidang keahlian yang ia tekuni maupun bidang-bidang lain yang terkait serta adanya keterampilan atau keahlian yang melekat dalam diri seorang guru, baik berupa kecakapan berbicara maupun kepiawaian dalam menempatkan diri.

Adapun macam-macam kompetensi guru dijelaskan dalam pasal 10 ayat (1) yang menyebutkan bahwa kompetensi guru meliputi: kompetensi pedagogik, kompetensi kepribadian, kompetensi sosial, dan kompetensi profesional yang diperoleh melalui pendidikan profesi. ${ }^{21}$

Berbeda dengan pendapat diatas, Nana Sudjana, A. Muri Yusuf, dan Rochman Natawidjaja dalam Syafruddin Nurdin sebagaimana dikutip oleh Ahmad Barizi, ia menyatakan bahwa terdapat sepuluh kompetensi dasar yang harus melekat dalam diri seorang guru, antara lain: 1) Menguasai bahan yang akan diajarkan, 2) Mengelola program belajar mengajar, 3) Mengelola kelas, 4) Menggunakan media/sumber belajar, 5) Menguasai landasan-landasan kependidikan, 6) Mengelola interaksi belajar mengajar, 7) Menilai prestasi siswa, 8) Mengenal huruf dan program bimbingan dan penyuluhan, 9) Mengenal dan menyelenggarakan administrasi sekolah, 10) Memahami prinsip-prinsip dan menafsirkan hasil penelitian. ${ }^{22}$

\section{Program Peningkatan Kompetensi Ustadz}

Peningkatan kompetensi ustadz bisa dilaksanakan melalui berbagai strategi, diantaranya:

a. Pendidikan dan pelatihan. Kegiatan ini meliputi: 1) Inhouse Training (IHT), 2) Program magang, 3) Kemitraan sekolah, 4) Belajar jarak jauh, 5) Pelatihan berjenjang dan pelatihan khusus, 6) Kursus singkat di LPTK atau lembaga pendidikan lainnya, 7) Pembinaan internal oleh sekolah, 8) Pendidikan lanjutan.

b. Kegiatan selain pendidikan dan pelatihan. Kegiatan ini meliputi: 1) Diskusi masalah pendidikan yang diselengarakan secara berkala dengan topik sesuai dengan masalah yang dialami sekolah, 2) Seminar, 3) Worshop, 4) Penelitian, 5) Penulisan buku atau bahan ajar, 6) Pembuatan media pembelajaran, 7) Pembuatan karya teknologi/karya seni. ${ }^{23}$

\section{Tugas dan Kewajiban Ustadz}

\footnotetext{
${ }^{20}$ Pupuh Fathurrohman \& Aa Suryana, Guru Profesional (Bandung: PT Refika Aditama, 2012), 18.

${ }^{21}$ Fathurrohman \& Aa Suryana, Guru Profesional, 18.

${ }^{22}$ Ahmad Barizi, Menjadi Guru Unggul (Jogjakarta: Ar-Ruzz Media, 2009), 141.

${ }^{23}$ I Nengah Martha, Pengantar Pendidikan (Yogyakarta: Graha Ilmu, 2014), 88-90.
} 
Profesi guru yang dalam hal ini adalah ustadz merupakan tugas yang sangat mulia, yaitu mewarisi tugas nabi dan rasul. Al-Qur'an dalam beberapa ayat mendeskripsikan tugas Rasul, yang selanjutnya juga menjadi tugas semua guru. 24 Ayat-ayat tersebut terdapat dalam surah-surah berikut:

a) Surah Al-Baqarah (2) ayat 129.

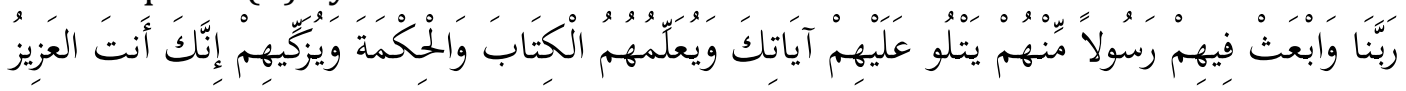

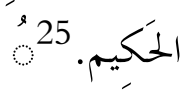

b) Surah Ali Imron (3) ayat 164 .

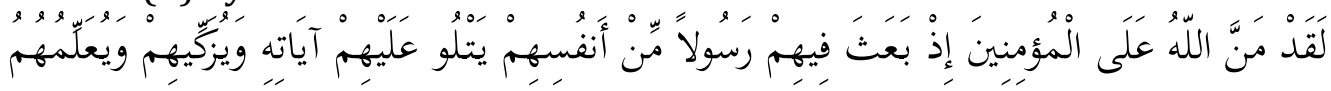

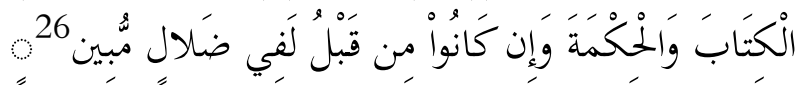

c) Surah Al-Jumu'ah (62) ayat 2.

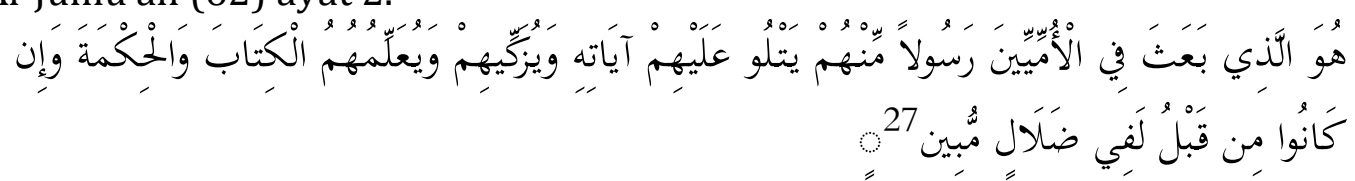

Ayat-ayat tersebut menegaskan bahwa ada tiga hal yang menjadi tugas Rasul yang juga menjadi tugas para ustadz, yaitu:

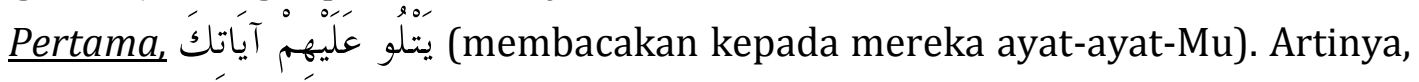
seorang guru dituntut agar dapat menyingkap fenomena kebesaran Allah yang terdapat dalam materi yang diajarkannya, sehingga para peserta didik dapat memahaminya dan mengikuti pesan-pesan yang terkandung di dalamnya.

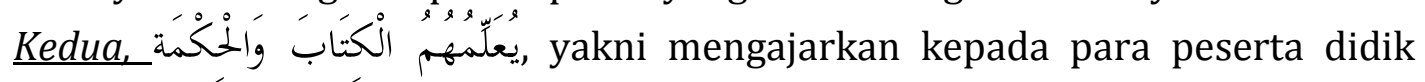
pesan-pesan normatif yang terkandung dalam kitab suci. Pesan-pesan tersebut berupa risalah ilahiah, yang meliputi keimanan, akhlak dan hukum yang mesti dipatuhi untuk kepentingan manusia dalam menjalani kehidupan didunia dan menghadapi kehidupan di akhirat.

Ketiga, يزكيّكم. Pendidik tidak hanya berkewajiban menanamkan ilmu pengetahuan, tetapi juga harus membangun moral dan atau membersihkan peserta didiknya dari sifat dan perilaku tercela. ${ }^{28}$

\footnotetext{
${ }^{24}$ Kadar M. Yusuf, Tafsir Tarbawi: Pesan-pesan Al-Qur'an tentang Pendidikan (Jakarta: Amzah, 2013), 65.

25 Departemen Agama Republik Indonesia, Al-Qur'an dan Terjemahannya (Bandung: Gema Risalah Press, 1989), 33.

26 Ibid., 104.

27 Ibid., 932.

${ }^{28}$ Yusuf, Tafsir Tarbawi, 67.
} 


\section{Syarat-syarat Ustadz}

Mengingat beratnya tugas dan tanggung jawab ustadz dalam Islam, tidak semua muslim bisa menjadi ustadz. Ada banyak persyaratan yang harus dipenuhi. Beberapa ahli pendidikan Islam telah merumuskan syarat-syarat yang harus dipenuhi seorang ustadz khususnya dari aspek kepribadian. Al-Gazali sebagaimana dikutip oleh Mohammad Kosim menyebut beberapa sifat yang harus dipenuhi ustadz, yaitu: (1) kasih sayang dan lemah lembut; (2) tidak mengharap upah, pujian, ucapan terima kasih atau balas jasa; (3) jujur dan terpercaya bagi murid-muridnya; (4) membimbing dengan kasih sayang, tidak dengan marah (5) luhur budi dan toleransi; (6) tidak merendahkan ilmu lain diluar spesialisasinya, (7) memperhatikan perbedaan inidividu, dan (8) konsisten. ${ }^{29}$

Menurut Sulani sebagaimana dikutip oleh Muhamad Nurdin, untuk mencapai tujuan pendidikan seorang guru harus memiliki syarat-syarat pokok sebagai berikut:

1) Syarat syakhsiyah (memiliki kepribadian yang dapat diandalkan).

2) Syarat ilmiah (memiliki ilmu pengetahuan yang mumpuni).

3) Syarat idhafiyah (mengetahui, menghayati dan menyelami manusia yang dihadapinya, sehingga dapat menyatukan dirinya untuk membawa anak didik menuju tujuan yang ditetapkan). ${ }^{30}$

Selain syarat-syarat tersebut, N. Yustisia juga mengemukakan bahwa ada beberapa hal yang perlu dikuasai seseorang ketika akan menjadi guru, diantaranya:

1) Menguasai materi yang akan diajarkan

2) Menguasai teori dan keterampilan mengajar, meliputi: (a) keterampilan menjelaskan, (b) keterampilan memberikan penguatan, (c) keterampilan bertanya, (d) keterampilan mengadakan variasi pembelajaran, (e) keterampilan membuka dan menutup proses pembelajaran, (f) keterampilan membimbing diskusi kelompok kecil, (g) keterampilan mengelola kelas, (h) keterampilan mengajar kelompok kecil dan perorangan. 31

\section{Pengertian dan Jenis-jenis Madrasah Diniyah}

Madrasah merupakan isim makan dari darasa yang memilki arti tempat untuk belajar. ${ }^{32}$ Dalam Kamus Istilah Agama Islam disebutkan bahwa madrasah adalah

\footnotetext{
${ }^{29}$ Kosim, Guru dalam Perspektif Islam, 7.

${ }^{30}$ Muhamad Nurdin, Kiat Menjadi Guru Profesional (Jogjakarta: Ar-Ruzz Media, 2008), 129.

${ }^{31}$ N. Yustisia, Hypno Teaching: Seni Ajar Mengeksplorasi Otak Peserta Didik (Jogjakarta: Ar-Ruzz Media, 2012), 22-27.

${ }^{32}$ Abdul Mujib, Ilmu Pendidikan Islam (Jakarta: Kencana Prenadamedia Group, 2014), 241.
} 
sekolah yang berbasis agama Islam. ${ }^{33}$ Sedangkan Diniyah berasal dari bahasa arab Ad-din yang artinya Agama. Jadi, penulis memahami bahwa madrasah diniyah ${ }^{34}$ adalah sebuah tempat atau lembaga pendidikan yang disediakan bagi orang-orang yang ingin mempelajari atau mendalami ilmu-ilmu agama.

Pendidikan diniyah adalah pendidikan keagamaan Islam yang diselenggarakan pada semua jalur dan jenjang pendidikan. ${ }^{35}$ Selanjutnya dalam Peraturan Pemerintah Pasal 14 ayat 2 disebutkan bahwa pendidikan diniyah diselenggarakan pada jalur formal, nonformal, dan informal. 36

Adapun Diniyah Takmiliyah yang selanjutnya disebut Madrasah Diniyah Takmiliyah adalah lembaga pendidikan keagamaan Islam pada jalur pendidikan nonformal yang diselenggarakan secara terstruktur dan berjenjang sebagai pelengkap pelaksanaan pendidikan agama Islam pada jenjang pendidikan dasar, menengah, dan tinggi. ${ }^{37}$ Penelitian ini fokus pada madrasah diniyah nonformal dalam bentuk madrasah diniyah takmiliyah.

Secara garis besar, Madrasah Diniyah Takmiliyah mempunyai tiga jenjang atau tingkatan, yaitu: Madrasah Diniyah Takmiliyah Awwaliyah (tingkat dasar), Madrasah Diniyah Takmiliyah Wustha (menengah pertama), dan Madrasah Diniyah Takmiliyah Ulya (menegah atas). ${ }^{38}$ Namun, untuk mempermudah dalam penyebutan tingkatantingkatan tersebut ada beberapa lembaga yang menggunakan istilah Ula, Wustha, dan Ulya.

\section{Sejarah Madrasah Diniyah}

Tumbuh dan berkembangnya madrasah di Indonesia tidak dapat dipisahkan dengan tumbuh dan berkembangnya ide-ide pembaharuan dikalangan umat Islam.

\footnotetext{
${ }^{33}$ Abu Muhammad FH \& Zainuri Ziroj, Kamus Istilah Agama Islam, 167.

34 Madrasah diniyah adalah suatu bentuk madrasah yang hanya mengajarkan ilmu-ilmu agama. (diniyah). Madrasah ini dimaksudkan sebagai lembaga pendidikan agama yang disediakan bagi siswa yang belajar di sekolah umum, dan keberadaannya dibentuk berdasarkan Keputusan Menteri Agama 1964, dengan materi pelajaran seluruh ilmu-ilmu agama Islam. Ijasah madrasah ini tidak memiliki civil effect, dan karena hal itulah baik orang tua maupun muridnya sendiri tidak begitu mementingkannya. Lihat M. Ridlwan Nashir, Mencari Tipologi Format Pendidikan Ideal: Pondok Pesantren di Tengah Arus Perubahan (Yogyakarta: Pustaka Pelajar, 2010), 95-96.

35 Peraturan Menteri Agama RI Nomor 13 Tahun 2014 tentang Pendidikan Keagamaan Islam (Jakarta: Kementerian Agama RI, 2014), 3.

36 Peraturan Pemerintah RI Nomor 55 Tahun 2007 tentang Pendidikan Agama dan Pendidikan Keagamaan (Jakarta: Presiden RI, 2007), 10.

${ }_{37}$ Peraturan Menteri Agama RI Nomor 13 Tahun 2014 tentang Pendidikan Keagamaan Islam (Jakarta: Kementerian Agama RI, 2014), 3.

${ }^{38}$ Ibid., 3.
} 
Menurut Sumardi sebagaimana dikutip oleh Haidar Putra Daulay, diantara ulama yang berjasa dalam menggagas tumbuhnya madrasah di Indonesia antara lain Syekh Abdullah Ahmad, pendiri Madrasah Adabiyah di Padang pada tahun 1909. Pada tahun 1915 Madrasah ini menjadi HIS Adabiyah yang tetap mengajarkan agama.

Madrasah Diniyah inilah yang kemudian berkembang di Indonesia, baik madrasah diniyah yang merupakan bagian dari pesantren atau surau, maupun yang berdiri diluarnya. ${ }^{39}$

"Pada perkembangan berikutnya, seiring dengan munculnya ide-ide pembaruan pendidikan agama dan atas dukungan pemerintah, sebagian lembaga pendidikan keagamaan yang beragam tersebut bersentuhan dengan metode klasikal modern yang terprogram. Proses ini kemudian mendorong lahirnya istilah "Madrasah Diniyah" atau "Pendidikan Diniyah". Masyarakat Islam diberbagai tempat menyelenggarakan dan mengembangkan pendidikan model ini dengan semangat kemandirian dan ketulusan yang didasari kesadaran akan pentingnya pemahaman dan penanaman nilai-nilai agama bagi para peserta didik. Butuh waktu yang tidak sedikit hingga akhirnya madrasah diniyah dan berbagai model pendidikan sejenisnya mendapatkan pengakuan sebagai bagian integral dari sistem pendidikan nasional."40

Berbeda halnya dengan Nor Huda, ia menyatakan bahwa lahirnya Madrasah Diniyah berawal dari dikeluarkannya SKB (Surat Keputusan Bersama) tiga Menteri No. 6 Tahun 1975, yang berdampak semakin surutnya pengetahuan agama lulusan madrasah dengan adanya perubahan kurikulum 70\% pelajaran umum dan hanya 30\% pendidikan agama. Dan menyikapi hal tersebut akhirnya Departemen Agama menetapkan dua jenis madrasah guna memudahkan pembinaan dan bimbingan. Jenis pertama yaitu madrasah yang selain menetapkan pelajaran agama sebagai mata pelajaran pokok, juga memasukkan mata pelajaran umum dalam kurikulumnya. Sedangkan jenis kedua yaitu madrasah yang semata-mata mempelajari agama, isi kurikulumnya semua pelajaran agama, dan madrasah inilah yang kemudian dikenal dengan Madrasah Diniyah. ${ }^{41}$

Kehadiran madrasah sebagai lembaga pendidikan Islam di Indonesia setidaknya mempunyai empat latar belakang, yaitu:

1) Sebagai manifestasi dan realisasi pembaharuan sistem pendidikan Islam.

\footnotetext{
39 Haidar Putra Daulay, Sejarah Pertumbuhan \& Pembaruan Pendidikan Islam (Jakarta: Kencana, 204), 98-99.

40 Direktorat Pendidikan Diniyah dan Pondok Pesantren, Pedoman Penyelenggaraan Madrasah Diniyah Takmiliyah (Jakarta: Kementerian Agama RI, 2014),1-2.

${ }^{41}$ Nor Huda, Sejarah Sosial Intelektual Islam di Indonesia (Jakarta: PT. RajaGrafindo Persada, 2015), 321-322.
}

149 | MODELING, Volume 6, Nomor 2, September 2019 


\section{Pembinaan Kompetensi Ustadz Madrasah Diniyah}

2) Usaha penyempurnaan terhadap sistem pesantren kearah suatu sistem pendidikan yang memungkinkan lulusannya untuk memperoleh kesempatan yang sama dengan sekolah umum, misalnya kesamaan kesempatan kerja dan perolehan ijazah.

3) Adanya sikap mental pada sementara golongan umat Islam, khususnya santri yang terpukau pada barat sebagai sistem pendidikan mereka, dan

4) Sebagai upaya untuk menjembatani antara sistem pendidikan tradisional yang dilakukan oleh pesantren dan sistem pendidikan modern dari hasil akulturasi. ${ }^{42}$

Dari berbagai uraian tersebut dapat dipahami bahwa latar belakang tumbuh dan berkembangnya Madrasah Diniyah berawal dari adanya keinginan untuk memupuk dan mengokohkan penguasaan agama para generasi penerus yang dalam hal ini adalah peserta didik serta adaya rasa kekhawatiran akan pupusnya pengetahuan agama para anak didik.

\footnotetext{
${ }^{42}$ Mujib, Ilmu Pendidikan Islam, 241.
} 


\section{Madrasah Diniyah sebagai Lembaga Pendidikan Islam}

Undang-undang Sisdiknas secara tegas dan eksplisit menyebutkan lembagalembaga pendidikan islam sebagai lembaga pendidikan nasional. Madrasah disebut sebagai lembaga pendidikan formal yang diakui baik pada jenjang pendidikan dasar maupun menengah. Demikian juga diniyah, pesantren, dan Raudhatul Athfal (RA) sebagai pendidikan khas Islam, semua disebut secara eksplisit dalam UU tersebut. ${ }^{43}$ Khususnya dalam pasal 30 ayat (4) disebutkan: "Pendidikan keagamaan berbentuk pendidikan diniyah, pesantren, pasraman, pabhaja samanera, dan bentuk lain yang sejenis". 44

Menurut An-Nahlawi sebagaimana dikutip oleh Muhammad Fathurrohman \& Sulistyorini, tugas madrasah sebagai lembaga pendidikan islam adalah:

1) Merealisasikan pendidikan Islam yang didasarkan atas prinsip pikir, akidah, dan tasyri' yang diarahkan untuk mencapai tujuan pendidikan.

2) Memelihara fitrah anak didik sebagai insan mulia, agar ia tak menyimpang dari tujuan Allah SWT menciptakannya.

3) Membersihkan pikiran dan jiwa dari pengaruh subjektivitas (emosi) karena pengaruh zaman dewasa ini lebih mengarah pada penyimpangan fitrah manusiawi.

4) Memberikan wawasan nilai-nilai moral, serta peradaban manusia yang membawa khazanah pemikiran anak didik menjadi berkembang.

5) Menciptakan suasana kesatuan dan kesamaan antar anak didik.

6) Menyempurnakan tugas-tugas lembaga pendidikan keluarga, masjid, dan pesantren. ${ }^{45}$

Dari uraian tersebut, dapat dipahami bahwasanya sebagai bagian dari lembaga pendidikan islam, madrasah diniyah harus mampu mentransformasikan nilai-nilai moral pada peserta didiknya sehingga anak didiknya tidak hanya pintar dalam segi penguasaan materi saja tapi juga bisa menerapkan ilmu yang diterima dalam kehidupan sehari-hari.

\section{Metode Penelitian}

Penelitian ini menggunakan pendekatan kualitatif. Peneliti menggunakan pendekatan kualitatif karena pendekatan ini dapat membantu peneliti menemukan dan menggali informasi tentang objek yang diteliti secara lebih mendalam sehingga bisa mengantarkannya untuk menemukan sebuah kebenaran melalui fenomenafenomena yang dijumpai.

\footnotetext{
${ }^{43}$ Sutrisno \& Muhyidin Albarobis, Pendidikan Islam Berbasis Problem Sosial (Jogjakarta: Ar-Ruzz Media, 2012), 47.

44 Ibid., 48.

${ }^{45}$ Fathurrohman \& Sulistyorini, Implementasi Manajemen Peningkatan Mutu Pendidikan Islam, 351353.
}

151 MODELING, Volume 6, Nomor 2, September 2019 
Berbeda halnya dengan Anselm Strauss \& Juliet Corbin, ia menyatakan bahwa ada beberapa alasan mengapa seorang peneliti menggunakan penelitian kualitatif, diantaranya: metode kualitatif dapat digunakan untuk mengungkap dan memahami sesuatu dibalik fenomena yang belum diketahui sedikitpun, sekaligus dapat memberikan tambahan wawasan. Selain itu, metode kualitatif juga dapat memberikan rincian yang kompleks tentang fenomena yang sulit diungkapkan oleh metode kuantitatif. ${ }^{46}$ Sedangkan jenis penelitian yang digunakan dalam penelitian ini adalah fenomenologi ${ }^{47}$, yakni ilmu tentang fenomena atau pembahasan tentang sesuatu yang menampakkan diri (manusia, gejala sosial,-budaya atau objek-objek lain. ${ }^{48}$

Penelitian ini mengambil lokasi di Madrasah Diniyah Takmiliyah Ar-Rosyidiyah Mambaul Ulum yang terletak di desa Gulbung Kec. Pangarengan Kab. Sampang. Salah satu hal yang menjadi pertimbangan bagi peneliti dalam pemilihan lokasi ini ialah karena lokasi Madrasah Diniyah Takmiliyah Ar-Rosyidiyah Mambaul Ulum ini mudah dijangkau oleh peneliti serta sudah menunjukkan kemajuan yang signifikan.

Mengingat kedukukannya peneliti yang begitu sinergis. Maka, dalam penelitian kualitatif keterlibatan seorang peneliti dalam kegiatan pengumpulan data maupun informasi adalah sebuah keharusan, karena kehadiran seorang peneliti dilapangan dan keaktifannya dalam mengikuti kegiatan yang sedang ia teliti akan memperkuat keakuratan hasil penelitiaanya kelak.

Dalam penelitian ini yang dijadikan sumber data manusia, yaitu: Ustadz yang mengikuti program pembelajaran, Kepala Madrasah, Kiai yang mengajar, dan siswa/i. Sedangkan data non manusia, yaitu: dokumen, fenomena dan fakta yang ditemui di lapangan. Sumber data sekunder ini dikumpulkan dengan maksud untuk menunjang sumber data primer.

Tehnik pengumpulan data dilakukan dengan metode wawancara, observasi, dan dokumentasi. Wawancara yang digunakan adalah jenis wawancara tidak terstruktur supaya bisa lebih leluasa dalam memperlebar pertanyaan, sebab bisa jadi ketika sedang melakukan wawancara akan ditemukan fakta-fakta baru yang bisa

\footnotetext{
46 Anselm Strauss \& Juliet Corbin, Dasar-dasar Penelitian Kualitatif: Tata Langkah dan Teknik-teknik Teorisasi Data (Yogyakarta: Pustaka Pelajar, 2013), 5.

${ }^{47}$ Fenomenologi adalah cara berfikir (metode) yang dikemukakan oleh Husserl pada awal abad ke-20. Ia memiliki nama lengkap Edmund Husserl dan lahir dikota kecil Proznitz daerah Moravia. Husserl berasal dari golongan Yahudi menengah. Namun, pada usia 27 tahun ia masuk protestan karena pengaruh temannya yakni G. Alberct. Husserl belajar matematika, filsafat,dan astronomi di Universitas Leipziq, Berlin, dan Wina. Minat pada filsafat tumbuh sewaktu Husserl mengikuti kuliah Franz Brentano pada tahun 1884-1886. Pada tahun 1901 pemikirannya tentang fenomenologi mencapai kematangan. Lihat Akhyar Yusuf Lubis, Filsafat Ilmu: Klasik hingga Komptemporer (Jakarta: PT RajaGrafindo Persada, 2016), 207.

48 Ibid., 205.
} 
dikembangkan. Observasi menggunakan jenis observasi partisipan karena peneliti bisa ikut serta dalam kegiatan yang hendak diteliti sehingga peneliti bisa mengamati objek penelitiaan secara langsung. Dan dokumentasi digunakan untuk melengkapi pengumpulan data selain wawancara dan observasi yang berkaitan dengan permasalahan-permasalahan yang diteliti.

Adapun untuk analisis data peneliti menggunakan langkah berikut: Reduksi Data, Display data, dan Kesimpulan. Dan untuk mengecek keabsahan data yang sudah diperoleh peneliti menggunakan teknik perpanjangan keikutsertaan, ketekunan pengamatan, dan triangulasi.

\section{HASIL PENELITIAN}

Penerapan Program Tarbiyatul Muallimin pada pembinaan kompetensi ustadz madrasah diniyah di Madrasah Diniyah Takmiliyah Ar-Rosyidiyah Mambaul Ulum Pangarengan Sampang

Program tarbiyatul mu'allimin merupakan sebuah wadah pembinaan yang diadakan untuk memberikan pembekalan sekaligus meningkatkan penguasaan materi seorang ustadz khususnya dalam bidang ilmu agama. Program ini mulai diterapkan pada tahun 2000 dengan tujuan untuk memupuk dan memperdalam pengetahuan dan pemahaman agama para asatidz.

Sebagaimana tujuannya yaitu untuk memupuk dan memperdalam pemahaman ilmu agama para asatidz. Maka, kajian materi dalam Program Tarbiyatul Mu'allimin adalah seputar kajian keagamaan. Dan materi atau kitab-kitab yang dikaji dan dipelajari dalam program Tarbiyatul Mu'allimin, meliputi: Riyadus Sholihin, Ta'limul Muta'allim, Tafsir Jalalain, Uqudul Lijen, Ibnu Aqil, Daqoiqul Akhbar, Fathul Qorib, Tauhid, Bidayatul Hidayah.

Program Tarbiyatul Mu'allimin dilaksanakan pada sore hari yaitu pada jam 15.30-16.30 WIB. Bentuk pelaksanaannya tidak berbeda dengan kegiatan pembelajaran seperti halnya yang terlaksana biasanya, yakni menggunakan sistem kelas dengan dipimpin oleh seorang kiai sebagai pengajarnya dan para asatidz sebagai peserta pembelajarannya. Dalam pelaksanaanya terdapat kegiatan pembuka, inti dan penutup. Kegiatan pembuka diawali dengan salam dan kemudian dilanjut dengan pembacaan nazhom alfiya bersama-sama. Sedangkan kegiatan inti di isi dengan kajian kitab yang mana disitu kiai yang membina membaca dan menjelaskan materi pelajaran sebagaimana yang sudah terjadwal dan didalamnya juga ada tanya jawab. Dan setelah itu penutup diisi dengan pembacaan do'a khotmi al-durūs. Metode yang digunakan dalam pelaksanaan program Tarbiyatul Mu'allimin yaitu metode ceramah dan tanya jawab.

Kendala atau hambatan yang dihadapi dalam penerapan Program Tarbiyatul Muallimin pada pembinaan kompetensi ustadz madrasah diniyah di Madrasah Diniyah Takmiliyah Ar-Rosyidiyah Mambaul Ulum Pangarengan Sampang 
Kendala atau hambatan adalah rintangan atau penghalang yang membuat pelaksanaan program tarbiyatul mu'allimin tidak bisa berjalan lancar sebagaimana harapan yang telah direncanakan.

Seperti kita ketahui bersama bahwasanya setiap upaya yang dilakukan ada kemungkinan akan menjumpai berbagai rintangan karena untuk bisa mencapai puncak keberhasilan harus mampu menaklukkan berbagai macam aral yang melintang. Dan tak terkecuali dalam penerapan program Tarbiyatul Mu'allimin, ada berbagai macam hambatan yang selalu mengiringi dan menghalangi sehingga tak bisa terlaksana dengan baik sebagaimana yang diharapkan. Seperti halnya waktu yang kurang memadai, kurangnya semangat dan keinginan para asatidz untuk konsisten dalam mengikuti program, aktifitas kemasyarakatan seperti tahlilan dan sejenisnya, serta kepentingan pribadi dari setiap asatidz.

Adanya hambatan-hambatan tersebut dapat memberikan dampak yang cukup signifikan dalam keefektifan program, bahkan bisa menyebabkan terjadinya kelumpuhan program. Dengan adanya hambatan tersebut membuat program berlangsung tersendat-sendat, adakalanya terlaksana adakalanya tidak. Dan pada akhirnya hal itu berdampak pada menurunnya semangat dari para asatidz untuk aktif mengikuti program tarbiyatul mu'allimin.

Solusi atau Cara mengatasi kendala yang dihadapi dalam penerapan Program Tarbiyatul Muallimin pada pembinaan kompetensi ustadz madrasah diniyah di Madrasah Diniyah Takmiliyah Ar-Rosyidiyah Mambaul Ulum Pangarengan Sampang

Solusi adalah sebuah pencarian jalan keluar atau pemecahan masalah terkait dengan problematika yang ada. Problematika yang telah membelenggu dan menimbulkan ketidak berdayaan dari beberapa pihak yang pada akhirnya dapat membuat terjadinya kelumpuhan program tidak bisa dibiarkan terus berkembang dan menyebar begitu saja. Perlu adanya sebuah upaya untuk bisa bangkit dari keterpurukan tersebut. Dan dalam hal ini pihak lembaga telah melakukan beberapa upaya sebagai wujud pencarian jalan keluar dari hambatan yang selama ini telah menghambat berlangsungnya program Tarbiyatul Muallimin.

Solusi yang dilakukan oleh pihak sekolah salah satunya yaitu berupa pemberian nasehat dan pemantapan akan pentingnya belajar sepanjang hayat bagi seorang ustadz guna menambah wawasannya sebagai bekal dalam menjalankan tugas dan tanggung jawabnya. Tindakan itu dijadikan solusi karena yang menghambat para asatidz untuk aktif dan konsisten mengikuti program karena adanya rasa malas dan kurangnya kesadaran akan pentingnya peningkatan kualitas diri.

Di samping itu, solusi yang dilakukan juga dengan cara memberikan tunjangan bagi para asatidz, yang mana jumlah tunjangan itu disesuaikan dengan keaktifan para asatidz dalam mengajar dan mengikuti program yang diadakan oleh lembaga. Hal itu dilakukan dengan pertimbangan untuk menambah semangat dan juga karena salah 
satu penghambat keaktifan asatidz untuk mengikuti program Tarbiyatul Mu'allimin adalah faktor ekonomi (sibuk bekerja).

155 | MODELING, Volume 6, Nomor 2, September 2019 


\section{PEMBAHASAN}

Penerapan Program Tarbiyatul Muallimin pada pembinaan kompetensi ustadz madrasah diniyah di Madrasah Diniyah Takmiliyah Ar-Rosyidiyah Mambaul Ulum Pangarengan Sampang

Pembinaan dan pengembangan profesi guru merupakan kewajiban sekolah dalam rangka menempatkan guru sebagai mitra profesi yang bergerak pada pelayanan jasa. Karenanya, pimpinan sekolah dalam hal ini memegang peranan penting untuk melaksanakan secara berkesinambungan. Upaya ini dilakukan untuk memberikan dorongan pada para guru agar tetap mempunyai semangat dan motivasi yang sama dalam mengemban tugasnya sebagai tenaga pendidik. ${ }^{49}$

Guru sebagai tenaga pendidik dituntut memiliki beberapa kompetensi guna menunjang kesuksesan tugas-tugasnya. ${ }^{50}$ Sebab, proses belajar dan hasil belajar para siswa bukan saja ditentukan oleh sekolah, pola, struktur, dan isi kurikulumnya. Akan tetapi, sebagian besar ditentukan oleh kompetensi guru yang mengajar dan membimbing mereka. Guru yang kompeten akan lebih mampu menciptakan lingkungan belajar yang efektif, menyenangkan, dan akan lebih mampu mengelola kelasnya, sehingga belajar para siswa berada pada tingkat normal. ${ }^{51} \mathrm{Hal}$ ini menunjukkan betapa pentingnya kompetensi seorang guru.

Munandar sebagaimana yang dikutip oleh Hamzah B. Uno dan Nina Lamatenggo menyatakan bahwa ada dua faktor yang mempengaruhi terbentuknya kompetensi, yakni faktor bawaan seperti bakat dan faktor latihan seperti belajar. ${ }^{52}$ Dari sini dapat dipahami bahwa kompetensi guru dapat dibentuk atau dipupuk melalui sebuah pembelajaran, baik pembekalan itu berupa sebuah latihan atau pembinaan dan semacamnya.

Para Stake Holder (Pemangku Pendidikan) di Madrasah Diniyah Ar-Rosyidiyah Mambaul Ulum menyadari akan hal itu. Sebuah kompetensi atau penguasaan guru terkait dengan materi ajar yang akan ia sampaikan pada anak didiknya mutlak diperlukan. Dan itulah tujuan utama diadakannya program Tarbiyatul Mu'allimin sebagaimana yang disampaikan oleh Kiai pembina Program tersebut bahwasanya tujuan utamanya untuk memperdalam ilmu pengetahuan para asatidz sehingga mempermudah mereka ketika mengajar. Kata orang madura makle magempang se ngajereh (supaya mudah dalam mengajar).

\footnotetext{
${ }^{49}$ Mujtahid, Pengembangan Profesi Guru (Malang: UIN Maliki Press, 2011), 70.

50 Moh. Roqib, Ilmu Pendidikan Islam: Pengembangan Pendidikan Integratif di Sekolah, Keluarga, dan Masyarakat (Yogyakarta: LKiS, 2009), 51.

${ }^{51}$ Oemar Hamalik, Pendidikan Guru: Berdasarkan Pendekatan Kompetensi (Jakarta: Bumi Aksara, 2010), 36.

${ }^{52}$ Hamzah B. Uno \& Nina Lamatenggo, Tugas Guru dalam Pembelajaran, 11.
} 
Dan hal ini sesuai dengan upaya peningkatan kompetensi ustadz yang dinyatakan oleh I Nengah Martha yang mana hal itu bisa dilaksanakan melalui berbagai strategi, diantaranya:

1. Pendidikan dan pelatihan. Kegiatan ini meliputi: a) Inhouse Training (IHT). Pelatihan dalam bentuk IHT adalah pelatihan yang dilaksanakan secara internal di KKG/MGMP, sekolah atau tempat lain yang ditetapkan untuk menyelenggarakan pelatihan, b) Program magang. Program magang adalah pelatihan yang dilaksanakan di institusi/industri yang relevan dalam rangka meningkatkan kompetensi profesional guru, c) Kemitraan sekolah. Pelatihan ini bisa dilaksanakan melalui kerjasama dengan institut pemerintah atau swasta dalam keahlian tertentu, d) Belajar jarak jauh, e) Pelatihan berjenjang dan pelatihan khusus. Pelatihan ini dilaksanakan di P4TK dan atau LPMP dan lembaga lain yang diberi wewenang, dimana program pelatihan disusun khusus secara berjenjang mulai dari jenjang dasar, menengah, lanjut dan tinggi, f) Kursus singkat di LPTK atau lembaga pendidikan lainnya, g) Pembinaan internal oleh sekolah, h) Pendidikan lanjutan.

2. Kegiatan selain pendidikan dan pelatihan. Kegiatan ini meliputi: a) Diskusi masalah pendidikan yang diselengarakan secara berkala dengan topik sesuai dengan masalah yang dialami sekolah, b) Seminar, c) Worshop, d) Penelitian, e) Penulisan buku atau bahan ajar, f) Pembuatan media pembelajaran, g) Pembuatan karya teknologi/karya seni. ${ }^{53}$

Dalam hal ini upaya yang dilakukan oleh pihak Madrasah Diniyah Ar-Rosyidiyah dalam pengadaan Program Tarbiyatul Mu'allimin termasuk dalam golongan upaya peningkatan kompetensi ustadz melalui Pendidikan dan Pelatihan yang dikemas dalam bentuk pembinaan internal oleh sekolah.

Kendala atau hambatan yang dihadapi dalam penerapan Program Tarbiyatul Muallimin pada pembinaan kompetensi ustadz madrasah diniyah di Madrasah Diniyah Takmiliyah Ar-Rosyidiyah Mambaul Ulum Pangarengan Sampang

Mengelola SDM bukan merupakan hal yang mudah, karena manusia merupakan unsur yang unik dan memiliki karakteristik yang berbeda antara satu dengan lainnya. ${ }^{54}$ Pengelola lembaga pendidikan Islam sering mendapatkan kesulitan untuk menyatukan pemikiran guru yang jumlahhnya besar meski mereka dituntut dapat mengajar dengan visi dan misi yang sama. 55

\footnotetext{
${ }_{53}$ Martha, Pengantar Pendidikan, 88-90.

${ }^{54}$ Ahmad Fatah Yasin, Pengembangan Sumber Daya Manusia di Lembaga Pendidikan Islam (Malang: UIN Maliki Press, 2011), 90.

55 Baharuddin, Pengembangan Lembaga Pendidikan Islam: Menuju Pengelolaan Profesional \& Kompetitif (Malang: UIN Maliki Press, 2011), 33.
} 
Kesulitan-kesulitan tersebut juga dialami dalam pembinaan kompetensi ustadz di Madrasah Diniyah Ar-Rosyidiyah Mambaul Ulum sebagaimana yang disampaikan oleh kiai pembina program bahwasanya dalam pelaksanaan program Tarbiyatul Mu'allimin terdapat banyak hambatan, diantaranya: keterbatasan waktu, dalam satu jam harus mengkaji dua kitab dan itu sangat kurang apalagi banyak kitab-kitab yang hanya dipelajari seminggu sekali. Kadang lagi asyik menjelaskan tahunya waktu sudah habis. Tapi yang sangat menghambat juga kurangnya kemauan dari para asatidz untuk belajar jadinya banyak yang sering tidak masuk. Dan selain itu, kalau ada undangan juga diliburkan dan kalau ada orang yang meninggal juga karena waktunya berbarengan dengan tahlilan.

Dan hal ini sesuai dengan pernyataan H.AR Tilaar sebagaimana dikutip oleh Saiful Arif bahwasanya dalam pembinaan dan pengembangan profesional ustadz pada realitasnya masih dijumpai adanya masalah. Terdapat kontradiksi di dalam persepsi guru atas program-program peningkatan profesional guru. Para guru cenderung ingin melihat hasilnya yang cepat, sedangkan pembinaan tersebut harus melalui pelaksanaan dilapangan sehingga meminta waktu yang cukup. Terdapat kontradiksi di dalam program pembinaan yang ingin mengumpulkan guru sebanyak mungkin dan oleh sebab itu program-program tersebut bersifat sangat dangkal. ${ }^{56}$

\section{Solusi atau Cara Mengatasi Kendala yang Dihadapi dalam Penerapan Program Tarbiyatul Muallimin pada Pembinaan Kompetensi Ustadz Madrasah Diniyah di Madrasah Diniyah Takmiliyah Ar-Rosyidiyah Mambaul Ulum Pangarengan Sampang}

Pembinaan dan pengembangan profesi guru memang menjadi tangung jawab kepala sekolah. Tetapi, semua upaya yang telah dilakukan sangat tergantung dari kemauan dan keantusiasan para guru. Namun, jika hal ini disadari dan dilaksanakan secara berkesinambungan, maka proses untuk meningkatkan kualitas lulusan sekolah akan tetap berkembang dan semakin baik. ${ }^{57}$

Dalam hal ini pembina program mencoba memberi pemantapan akan pentingnya mengikuti program Tarbiyatul Mu'allimin untuk menambah penguasaan materi-materi yang akan diajarkan pada murid-muridnya nanti.

Meskipun upaya pertama yang sudah dipaparkan sebelumnya menunjukkan adanya sebuah perubahan atau kemajuan. Namun, kenyataan empirik menunjukkan bahwa manusia bekerja karena menginginkan sesuatu seperti gaji, penghargaan, pemanfaatan waktu, mencapai karier, mencukupi kebutuhan hidup dan berbagai alasan lainnya. Dan dalam hal ini upaya memberikan kontribusi produktif seakan

\footnotetext{
${ }^{56}$ Arif, "Orientasi Pembinaan dalam Tadris, 143.

${ }^{57}$ Mujtahid, Pengembangan Profesi Guru, 71.
} 
menjadi win-win solution karena dengan begitu manusia yang bekerja sekaligus bisa memenuhi tujuannya dalam bekerja. ${ }^{58}$

Terkait dengan perihal tersebut pihak madrasah Ar-Rosyidiyah Mambaul Ulum berupaya mencari pilihan tindakan dalam mengatasi hambatan yang ada sebagaimana penuturan KH. Abd. Wahid Rosyidi yakni karena pengahalang para asatidz untuk bisa aktif mengikuti program adalah urusan pekerjaan yang berkaitan dengan nafkah. Jadi, saya berinisiatif untuk memberikan sebuah tambahan uang jajan dengan harapan bisa menambah semangat para ustadz sehingga giat mengajar dan mengikuti kegitan-kegiatan yang diadakan oleh sekolah. Dan nominalnya pun saya sesuaikan dengan keaktifan para ustadz itu.

\section{Kesimpulan}

Program tarbiyatul mu'allimin dilaksanakan pada sore hari setelah para asatid dan asatidzah selesai melaksanakan tugasnya dalam mengajar, tepatnya pada jam 04.00-05.00 (istiwa') yakni setelah selesai melaksanakan shalat berjama'ah dengan para murid/santri bagian putra. Bentuk pelaksanaannya sama dengan KBM yang dilaksanakan dikelas biasanya. Dan materi kajiannya meliputi 8 bidang ilmu, yaitu: (1) Ilmu Ushul, disini kitab yang digunakan adalah Jawharotat Tauhid, (2) ilmu Furu', kitabnya Fathul Qarib, (3) Tafsir, ini menggunakan kitab Tafsir Jalalain, (4) ilmu Hadist, kitab yang digunakan Riyadus Sholihin, (5) ilmu alat, kitabnya Ibnu aqil, (6) ilmu Qushos kitab kajiannya Daqoiqul Akhbar, (7) ilmu sufi, kitab yang dikaji Bidayatul Hidayah, dan yang terakhir atau kedelapan (8) adalah ilmu Akhlak, kitab yang dikaji Ta'limul Muta'allim dan Uqudul Lijain.

Hambatan yang dihadapai dalam penerapan program Tarbiyatul Mu'allimin, yaitu: (1) Keterbatasan waktu (2) Minimnya minat atau kemauan para asatidz untuk belajar (3) Padatnya aktivitas baik pembina maupun asatidz

Dalam mengatasi hambatan yang ada pihak Madrasah Diniyah Ar-Rosyidiyah Mambaul Ulum khususnya yang terlibat dalam program Tarbiyatul Mu'allimin seperti Kepala sekolah dan kiai pembina program mencoba memberi pemantapan dan meyakinan para asatidz akan pentingnya mengikuti program Tarbiyatul Mu'allimin untuk menambah dan memperluas penguasan materi yang akan disampaikan para murid-muridnya. Selain itu, kepala sekolah juga mengambil pilihan tindakan dengan pemberian tunjangan yang nominalnya disesuaikan dengan keaktifan para ustadz dalam mengajar dan mengikuti program yang diadakan oleh pihak sekolah/madrasah. Dan terkait dengan alokasi waktu yang terbatas diupayakan adanya penambahan jam.

\section{Daftar Pustaka}

${ }^{58}$ Jusmaliani, Pengelolaan Sumber Daya Insani (Jakarta: Bumi Aksara, 2014), 40.

159 | MODELING, Volume 6, Nomor 2, September 2019 
Arif, Saiful. 2013. "Orientasi Pembinaan dan Pengembangan Profesi Guru di Madrasah." Tadris,8 (1): 143.

Baharuddin. 2011. Pengembangan Lembaga Pendidikan Islam: Menuju Pengelolaan Profesional \& Kompetitif. Malang: UIN Maliki Press.

Barizi, Ahmad. 2011. Pendidikan Integratif; Akar Tradisi \& Integrasi Keilmuan Pendidikan Islam. Malang: UIN Maliki Press.

----------. 2009. Menjadi Guru Unggul. Jogjakarta: Ar-Ruzz Media.

Daulay, Haidar Putra. 2014. Sejarah Pertumbuhan \& Pembaruan Pendidikan Islam di Indonesia. Jakarta: Kencana.

Departemen Agama Republik Indonesia. 1989. Al-Qur'an dan Terjemahannya. Bandung: Gema Risalah Press.

Digilib.unila.ac.id/930/9/BAB II.pdf. Diakses 26 April 2017.

Direktorat Pendidikan Diniyah dan Pondok Pesantren. 2014. Pedoman Penyelenggaraan Madrasah Diniyah Takmiliyah. Jakarta: Kementerian Agama RI.

Fathurrohman, Muhammad \& Sulistyorini. 2012. Implementasi Manajemen Peningkatan Mutu Pendidikan Islam; Peningkatan Pendidikan Islam Secara Holistik (Praktik \& Teoritk). Yogyakarta: Teras.

Fathurrohman, Pupuh \& Aa Suryana. 2012. Guru Profesional. Bandung: PT Refika Aditama.

FH, Abu Muhammad \& Zainuri Ziroj. 2009. Kamus Istilah Agama Islam (KIAI). Tangerang: PT Albama.

Hamalik, Oemar. 2010. Pendidikan Guru: Berdasarkan Pendekatan Kompetensi. Jakarta: Bumi Aksara.

Herabudin. 2009. Administrasi \& Supervisi Pendidikan. Bandung: Pustaka Setia.

Huda, Nor. 2015. Sejarah Sosial Intelektual Islam di Indonesia. Jakarta: PT. RajaGrafindo Persada.

Kompri. 2015. Manajemen Pendidikan: Komponen-Komponen Elementer Kemajuan Sekolah. Yogyakarta: Ar-Ruzz Media.

Kosim, Mohammad. 2013. Guru dalam Perspektif Islam. Dalam Mohammad Muchlis Solichin (Ed.), Memotret Guru Ideal-Profesional: Harapan, Peluang, dan Tantangan di Tengah Arus Perubahan Sosial (hlm. 4). Surabaya: Pena Salsabila.

Kurniawan, Hendrikus Lyzardi et al. 2014. Pembinaan Sumber Daya Aparatur dalam Upaya Meningkatkan Kinerja Pegawai pada Bagian Ekonomi Sekretariat Daerah Kabupaten Kutai Barat. eJournal Administrative Reform, 2 (3).

Lubis, Akhyar Yusuf. 2016. Filsafat Ilmu: Klasik hingga Komptemporer. Jakarta: PT RajaGrafindo Persada.

Martha, I Nengah. 2014. Pengantar Pendidikan. Yogyakarta: Graha Ilmu.

Muhaimin. 2010. Pengembangan Kurikulum Pendidikan Agama Islam di Sekolah, Madrasah, dan Perguruan Tinggi. Jakarta: PT Raja Grafindo Persada.

Mujib, Abdul. 2014. Ilmu Pendidikan Islam. Jakarta: Kencana Prenadamedia Group.

Mujtahid. 2011. Pengembangan Profesi Guru. Malang: UIN Maliki Press. 
Nashir, M. Ridlwan. 2010. Mencari Tipologi Format Pendidikan Ideal: Pondok Pesantren di Tengah Arus Perubahan. Yogyakarta: Pustaka Pelajar.

Nokesteen, Mehdi. t.tt. History of Islamic Origins of Western Education. Colorado: University of Colorado Press.

Nurdin, Muhamad. 2008. Kiat Menjadi Guru Profesional. Jogjakarta: Ar-Ruzz Media.

Pengertian, Fungsi Pembinaan Menurut Para Ahli, Kumpulan Artikel tentang Komputer, Internet, dan juga Pelajaran Sekolah dan Artkel Lainnya:http://xerma.blogspot.co.id/2014/05/pengertian-fungsi-pembinaanmenurut.html. Diakses 25 April 2017.

Peraturan Menteri Agama RI Nomor 13 Tahun 2014 tentang Pendidikan Keagamaan Islam. 2014. Jakarta: Kementerian Agama RI.

Peraturan Pemerintah RI Nomor 55 Tahun 2007 tentang Pendidikan Agama dan Pendidikan Keagamaan. 2007. Jakarta: Presiden RI.

Peraturan Pemerintah RI Nomor 74 Tahun 2008 tentang Guru. 2008. Jakarta: Presiden RI.

Rani. Upaya Pembinaan Kompetensi Profesinal Guru: http://raniaja606/.blogspot.co.id/2014/05/upaya-pembinaan-kompetensiprofesional.html. Diakses 26 April 2017.

Roqib, Moh. 2009. Ilmu Pendidikan Islam: Pengembangan Pendidikan Integratif di Sekolah, Keluarga, dan Masyarakat. Yogyakarta: LKiS.

Sardiman. 2010. Interaksi \& Motivasi Belajar Mengajar. Jakarta: PT Raja Grafindo Persada.

Strauss, Anselm \& Juliet Corbin. 2013. Dasar-dasar Penelitian Kualitatif: Tata Langkah dan Teknik-teknik Teorisasi Data. Yogyakarta: Pustaka Pelajar.

Sutrisno \& Muhyidin Albarobis. 2012. Pendidikan Islam Berbasis Problem Sosial. Jogjakarta: Ar-Ruzz Media.

Tim Penyusun Kamus Pusat Bahasa. 2008. Kamus Besar Bahasa Indonesia, offline. Jakarta: Pusat Bahasa.

Uno, Hamzah B. \& Nina Lamatenggo. 2016. Tugas Guru dalam Pembelajaran: Aspek yang Memengaruhi. Jakarta: Bumi Aksara.

Yasin, Ahmad Fatah. 2011. Pengembangan Sumber Daya Manusia di Lembaga Pendidikan Islam. Malang: UIN Maliki Press.

Yusuf, Kadar M. 2013. Tafsir Tarbawi: Pesan-pesan Al-Qur'an tentang Pendidikan. Jakarta: Amzah.

Yustisia, N. 2012. Hypno Teaching: Seni Ajar Mengeksplorasi Otak Peserta Didik. Jogjakarta: Ar-Ruzz Media.

161 | MODELING, Volume 6, Nomor 2, September 2019 